\title{
Availability of crop by-products in Spain: new raw materials for natural thermal insulation
}

\author{
M. Palumbo a,", J. Avellaneda ${ }^{\text {b }, ~ A . M . ~ L a c a s t a ~}{ }^{a}$ \\ ${ }^{a}$ EPSEB, Universitat Politècnica de Catalunya, Barcelona, Spain. \\ ${ }^{b}$ ETSAV, Universitat Politècnica de Catalunya, Barcelona, Spain. \\ *Corresponding author: UPC-EPSEB, Av Dr. Marañon 44-50 08028 Barcelona. \\ Tel: +34/934016816 E-mail: mariana.palumbo@upc.edu
}

\begin{abstract}
Vegetal materials were one of the first construction materials used by humans, but the development of petrol-based synthetic materials in the last century replaced them in mainstream construction techniques. However, since environmental impact and resource depletion are increasingly becoming a central issue, vegetal materials are revisited. Natural thermal insulations are mainly developed from woody materials and industrial fibres, but these raw materials are not always locally available. Thus, the use of crop by-products is proposed here. The availability of crop by-products to be used as raw materials for building thermal insulations in Spain is evaluated. It is then compared to demand forecasts based on two different scenarios. Results vary greatly from one scenario to another, but they indicate that the amount of crop byproducts is sufficient to meet estimated demand. Barley and wheat straw are by far the most abundant by-products, followed by corn, rice and sunflowers. Available corn by-products would be sufficient to insulate between 250,000 and 450,000 dwellings yearly.
\end{abstract}

Keywords: food crop by-products, natural thermal insulation materials, cereal straw, corn stalks

\section{Introduction}

Intervention in existing building stocks (including the implementation of optimized thermal insulation systems) is a key strategy for tackling the challenges posed by the European Commission targets for reducing greenhouse gases (GHG) emissions by 2020 and 2050. Such targets urge member countries to reduce the internal GHG emissions by $20 \%$ in 2020 and $80 \%$ in 2050 with respect to their 1990 emissions levels [1,2]. Specifically in Spain, it is estimated that 10 million dwellings should be refurbished between now and 2050 to meet these challenges $[1,3]$. Therefore, environmental impacts derived from this activity, such as energy use, CO2 emissions or depletion of non-renewable resources, must be taken into account.

The use of natural thermal insulation materials could be an alternative to reduce environmental impacts. However, these products are still only marginally used. In 2013, mineral wools and organic foams -both produced from non-renewable raw materials- accounted for about $98 \%$ of the market share in Spain [4]. The renewable alternative, i.e. natural thermal insulation materials, represented less than $2 \%$ of the market (see Figure 1). Furthermore, most of these materials were imported, with some exceptions such as Termofitex Lan (sheep wool), RMTNITA products (sheeps' wool, textile waste or hemp fibre), Cannabric products (hemp based) 
and Aislanat (cellulose). Several factors prevent natural thermal insulations from having a greater presence in the market, such as regulations, lack of label certifications, production costs, and lack of incentives and uncertainty of policies, among others [5,6]. Nevertheless, it is reasonable to forecast a growing demand for these products in the coming years, due to the increasing concern about environmental issues and changes in policies.

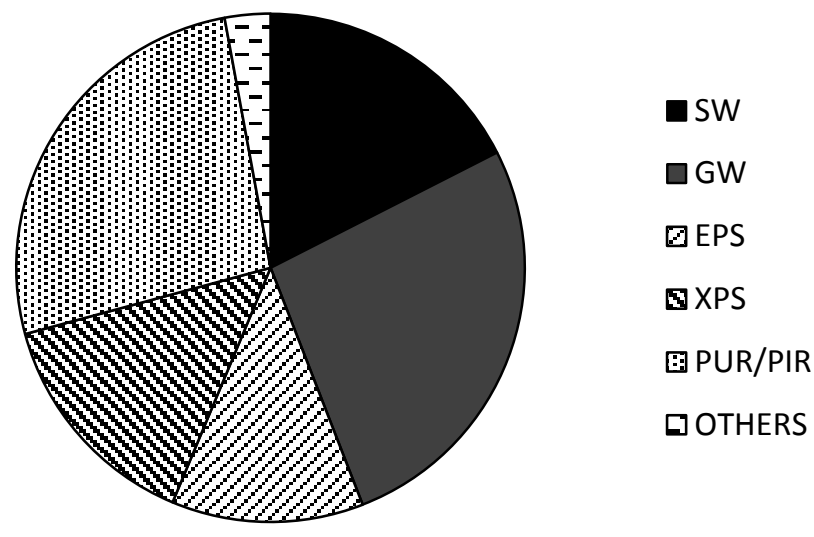

Figure 1. Bt and Ba produced annually in Spain (dry basis).

The present study analyses the potential for the development of natural thermal insulation materials based on crop by-products in Spain. Normally, industrial fibres (mainly hemp, flax or kenaf), cellulose and wood fibres are used as raw materials for these products, but these raw materials are relatively scarce in Spain, especially compared with agriculture production [7]. The use of crop by-products may therefore offer an interesting alternative to existing insulation materials. Moreover, they present many other advantages, such as:

- They are renewable annually, in contrast to wood, which has longer regeneration cycles.

- They are compostable, which may contribute to the reduction of waste going to landfills, and to the development of an industry based on closed production cycles where the concept of waste disappears [8].

- They are easily accessible and do not compete in fertile land use with food production, as is the case of industrial fibres.

- Their valorisation may contribute to diversify the market for farmers [5]. Moreover, it may contribute to the use of native species that have not been modified to increase their harvest index.

- Their internal structure makes them naturally low thermal conductors, which may mean that they do not need to be highly transformed to achieve the thermal requirements for insulation materials [9].

- Their hygroscopic behaviour may contribute to maintaining comfort in buildings [10].

The availability of crop by-products is investigated in order to assess the feasibility of their use as raw materials for natural thermal insulations. This is then contrasted with an estimation of demand based in two different scenarios. A similar analysis conducted in France [11] estimates that to insulate an average of 400,000 new dwellings per year with straw bales, about 2 MT of straw would be necessary. This amount represents $4 \%$ of straw produced in that country yearly.

A large number of studies exist that evaluate the availability of agricultural residues (both for the EU as a whole and for particular state members), focusing on their use as a renewable source 
of energy [12-17]. Jölli and Giljum [18] carried out an extensive review of the literature, highlighting the scarcity of comprehensive data about this subject.

According to Jölli and Giljum, important discordances were detected in the reviewed literature, both for the estimation of the total crop by-products (Bt) and the available crop by-products $(\mathrm{Ba}) . \mathrm{Bt}$ is calculated either from crop surface area $(\mathrm{S})$ or from crop production $(\mathrm{p})$ and $\mathrm{Ba}$ corresponds to a certain percentage of Bt. The difference between $\mathrm{Bt}$ and $\mathrm{Ba}$ are the unavailable by-products that either are destined for other uses $(\mathrm{Bu})$ or reincorporated into soils to maintain their productivity (Bf) (as expressed in Eq. 1). The determination of the unavailable by-products widely varies from author to author as it depends on local factors such as the type of farming practices, the climatic conditions or the kind of soil which are not easy to include in large scale estimations. Moreover, there is an open discussion on what is the amount of by-products that should be retained in the soils in a sustainable production and the authors didn't found any conclusive data on this issue.

$$
B a=B t-B u-B f
$$

Discordances on weighting $\mathrm{Bu}$ and $\mathrm{Bf}$, as well as differences in methodology are posited on the basis of the differences in results found in the literature. The different Bt calculations encountered in literature review are summarised in Table 1. Then the weighting of $\mathrm{Bf}, \mathrm{Bu}$ and Ba are shown.

Table1. Methodology and assumptions used by different authors. HI and mc correspond to harvest index and moisture content, respectively. RPR stands for residue to product ratio.

\begin{tabular}{|c|c|c|c|c|c|}
\hline Author & By-product & Bt & Bf $(\%)$ & Bu (\%) & Ba $(\%)$ \\
\hline \multirow{2}{*}{$\begin{array}{l}\text { Ericsson and } \\
\text { Nilsson } 2005\end{array}$} & Maize & $\mathrm{Bt}=1 \mathrm{p}$ & 75 & 0 & 25 \\
\hline & Other cereals & $\mathrm{Bt}=1.3 \mathrm{p}$ & 75 & 8.25 & 16.75 \\
\hline $\begin{array}{l}\text { Fischer et al. } \\
2007\end{array}$ & Cereals & $\mathrm{Bt}=\mathrm{p} \cdot \mathrm{RPR} \cdot(1-\mathrm{mc})$ & 50 & 0 & 50 \\
\hline BNEF 2010 & Cereals & $\mathrm{Bt}=\mathrm{p} \cdot[(1-\mathrm{HI}) / \mathrm{HI}]$ & 75 & 7.5 & 17.5 \\
\hline $\begin{array}{l}\text { Hernández and } \\
\text { Fuertes } 2011\end{array}$ & Cereals & $\mathrm{Bt}=\mathrm{p} \cdot[(1-\mathrm{HI}) / \mathrm{HI}] \cdot(1-\mathrm{mc})$ & 0 & 50 & 50 \\
\hline \multirow{2}{*}{ WWF 2011} & Rice & \multirow{2}{*}{$\mathrm{Bt}=10 \cdot \mathrm{S}$} & - & - & 30 \\
\hline & Cereals & & - & - & 35 \\
\hline \multirow{3}{*}{ Di Blasi 1997} & Sunflower & & & $0-10$ & $90-100$ \\
\hline & Rice & $\mathrm{Bt}=\mathrm{S} \cdot$ Byeld $\cdot(1-\mathrm{mc})$ & 0 & $15-30$ & $70-85$ \\
\hline & Other cereals & & & $40-60$ & $40-60$ \\
\hline \multicolumn{2}{|c|}{ Average* } & & 40 & 23 & 37 \\
\hline
\end{tabular}

*Only figures for "cereals" and "other cereals" are taken into account.

Estimations carried out by the Bloomberg New Energy Finance (BNEF) [12] show that about $80 \%$ of the 2020 biomass residue supply in EU-27 will come from the agricultural sector. These estimations were made under the assumption that only $17.5 \%$ of the total crop by-products is available, which may be considered a conservative assumption [6]. For the rest, 75\% was returned to fields and $7.5 \%$ was destined for other uses. Wheat straw, sugar beet residues, barley straw and maize stover were signalled as the main crop by-products available, which accounts for about 156 MT. BNEF also estimated that the biomass residue supply for 2020 in Spain will 
be between 19 and 23 MT (i.e., between 15 and 18.4 MT of crop by-products), which puts this country among the top five biomass producers in Europe.

Fischer et al. [16] used data from FAOSTAT to estimate crop by-products production and built two possible scenarios up to 2030. According to their work, Bt produced yearly in EU-27 between 2000 and 2002 would be 457 MT, of which about 215 MT would correspond to Ba, approximately three-quarters of which would come from cereals. The authors estimated a decrease in crop by-products production by 2030 due to yield increases.

Ericsson and Nilsson [17] calculated the energy produced from cereal (wheat, barley, rye and oats) and maize residues for EU-15. Data was taken from FAO and average yields between 1998 and 2002 were used for calculation. Bt was calculated from grain production, establishing a ratio of 1.3 straw to grain for cereals and 1 for maize. It was assumed that only $25 \% \mathrm{of} \mathrm{Bt}$ would be harvested and that a third of the harvested Bt would already have been used in existing activities.

Several further works are found that refer to crop by-products outcome in Spain [19,22-23]. All these studies rely either totally or partially on the data provided by the Spanish Ministerio de Agricultura, Alimentación y Medioambiente (MARM) [7]. Statistical data from MARM is created from on-site enquires (ESYRCE) and data compiled from regional organisms. Crops are divided into 13 categories and information on production, crop areas and agricultural yield, among many others, is provided yearly. The statistical year-book also includes the volume of harvested straw, i.e. straw already used, which is usually estimated to represent $50-55 \%$ of total straw production $[13,19,25]$.

Hernandez and Fuertes [19] quantified the total biomass production in Spain from 2005 to 2007. It was found that an average of 17.4 MT of crop by-products was produced yearly. Among these, $83 \%$ was cereal straw (about 14.5 MT). In this case, Ba for cereals corresponded to 50\% of their Bt. Similar results were presented by IDAE (Instituto para la Diversificación y Ahorro de la Energía) in the PER11-20 [22]. In this work, crop by-products referred only to cereal straw and corn stalks and $\mathrm{Bu}$ was estimated to be $50 \%$ of Bt. The results were in concordance with those of Hernandez and Fuertes (14.5 MT). Neither of these two works considers Bf, although it seems to be a relevant factor, especially in Spain, where more than the $50 \%$ of the soils are classified as medium-high risk of desertification [22].

Actually, the amount of crop by-products that should be returned to fields to prevent significant impact is under discussion. No conclusive data exist in this regard, in part because it depends to a large extent on specific local conditions [16]. In the case of cereals, it was generally assumed that $50 \%$ of the straw could be removed without any significant impact on soil fertility or soil erosion [16,25], but recent studies tend to be more conservative. A report carried out by WWF [26] indicated that, generally, an extraction rate between $20 \%$ and $40 \%$ is recommended, while BNEF [12] assumed an extraction rate of $25 \%$ in accordance with the recommendations of the International Energy Agency.

Martinez [27] estimated that the average loss of humus in Spanish fields is $700 \mathrm{Kg} / \mathrm{ha} \cdot$ year, with a notable variation from one field to another. For cereals, it is estimated that roots and stubble (which account for $60-80 \%$ of the total straw) can provide between 300 and $1000 \mathrm{~kg} / \mathrm{ha} \cdot$ year of humus [28], which leaves a margin for straw exploitation. However, experiments carried out on non-irrigated cereal crops in Andalucía [23] show that humus can increase by about $100 \%$ in 20 years when incorporating all the straw, and in general the more straw that is left the better. 
On the other hand, the intensity of current crop production may impede the incorporation of crop by-products in the soil, as degradation cannot take place over such short periods of time. To improve degradation, by-products are triturated and Nitrogen is added or the materials are composted somewhere else before being incorporated. The speed of degradation depends on several factors, but in Spain the most restrictive of these is low rainfall during summer periods. Cereal straw, and especially pruning waste, degrade slowly due to their high $\mathrm{C} / \mathrm{N}$ ratio [27].

\section{Methodology}

\subsection{Availability of crop by-products}

Estimation of the total crop by-products $(\mathrm{Bt})$ produced yearly was undertaken for the period 2008-2010 using baseline data from MARM [7]. The methodology used was chosen from reviewed literature. To this end, $\mathrm{Bt}$ and $\mathrm{Ba}$ were estimated using the same input data and following the different methodologies shown in Table 1. Results are presented in Table 2. It was found that Ba may vary over $100 \%$ depending on the methodology used. However the one described by Hernandez and Fuertes [19] was eventually used, since this was considered to be the most complete and results for Ba were near the average.

Table 2. Bt and $\mathrm{Ba}$ are estimated using the same input data and following the different methodologies found in the literature. Results include only cereals and sunflowers. Input is taken from MARM [7] for 2010 and from Hernandez and Fuertes [19].

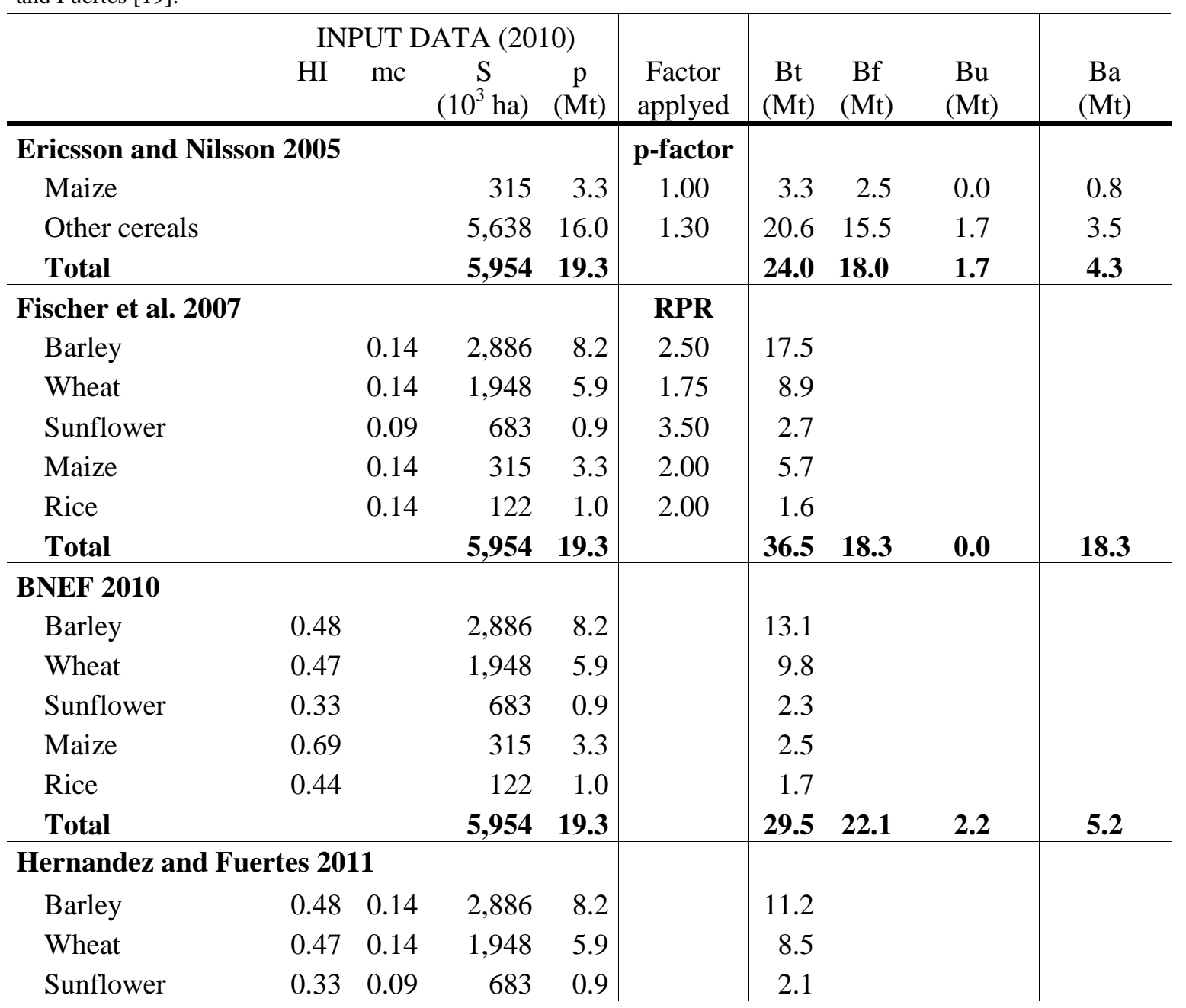




\begin{tabular}{|c|c|c|c|c|c|c|c|c|c|c|c|}
\hline Maize & 0.69 & 0.14 & 315 & 3.3 & & 2.2 & & \multirow{3}{*}{\multicolumn{2}{|c|}{12.7}} & \multirow{3}{*}{\multicolumn{2}{|c|}{12.7}} \\
\hline Rice & 0.44 & 0.14 & 122 & 1.0 & & 1.5 & & & & & \\
\hline Total & & & 5,954 & 19.3 & & 25.5 & 0.0 & & & & \\
\hline \multicolumn{12}{|l|}{ WWF 2011} \\
\hline Rice & & & 122 & 1.0 & & 1.2 & & & & & .4 \\
\hline Other cereals & & & 5,831 & 18.3 & & 58.3 & & & & 20 & .4 \\
\hline Total & & & 5,954 & 19.3 & & 59.5 & & & & 20 & .8 \\
\hline \multicolumn{5}{|l|}{ Di Blasi 1997} & Byeld & & & & & & \\
\hline Barley & & 0.14 & 2,886 & 8.2 & 1.20 & 3.0 & & 1.8 & 1.2 & 1.2 & 1.8 \\
\hline Wheat & & 0.14 & 1,948 & 5.9 & 2.40 & 4.0 & & 2.4 & 1.6 & 1.6 & 2.4 \\
\hline Sunflower & & 0.09 & 683 & 0.9 & 0.50 & 0.3 & & 0.0 & 0.0 & 0.3 & 0.3 \\
\hline Maize & & 0.14 & 315 & 3.3 & 7.80 & 2.1 & & 1.3 & 0.9 & 0.9 & 1.3 \\
\hline Rice & & 0.14 & 122 & 1.0 & 0.80 & 0.1 & & 0.0 & 0.0 & 0.1 & 0.1 \\
\hline Total & & & 5,954 & 19.3 & & 9.5 & 0.0 & 5.5 & 3.7 & 4.0 & 5.8 \\
\hline AVERAGE & & & & & & & & & & & 0.9 \\
\hline
\end{tabular}

As shown in Eq. 2, Bt (dry basis) was estimated from grain production (p) by applying a convertor factor, the harvest index (HI), and a corrective factor related with the amount of moisture naturally present in crop by-products $(\mathrm{mc})$. HI and mc were regarded as constant and specific to each crop type, and their values were taken from Hernandez and Fuertes [19]. HI values established by these authors were similar to those listed by Ericsson and Nilsson [17] for all crops except for maize, which varied from 0.69 to 0.41. Ba was equal to $\mathrm{Bt}$ for all crops except from cereals and industrial crops, where it was assumed that Ba corresponded to $37 \%$ of Bt. This corresponds to the average percentage found in the reviewed literature (see Table 1).

$$
B t=p\left(\frac{1-H I}{H I}\right)(1-m c)
$$

\subsection{Estimation of demand for insulation materials}

Two scenarios are established to estimate the demand of crop by-products as raw materials for natural thermal insulations.

The first scenario is established according to the GTR reports [1,3]. These two reports base a forecast on the number of homes that can be refurbished yearly in Spain up to 2050 (between 250,000 and 450,000), and the thermal transmission coefficient of the envelope that would be necessary to achieve a reduction in energy consumption of $80 \%$. In all cases, values of thermal transmission are more restrictive than those established by the current Spanish regulation.

This data is crossed with the average thermal conductivity and density of existing natural thermal insulation materials. Values for conductivity and density (shown in Table 3) are taken from the literature and from manufacturers, and are used to estimate the volume of insulation needed. 
Table 3. Density and thermal conductivity of existing NFI materials. ${ }^{1}$ Data from existing NFI materials. ${ }^{2}$ Data from the literature [29].

\begin{tabular}{llll}
\hline Raw material & $\begin{array}{l}\text { Form of } \\
\text { supply }\end{array}$ & $\begin{array}{l}\text { Density } \\
(\mathrm{kg} / \mathrm{m} 3)\end{array}$ & $\begin{array}{c}\boldsymbol{\lambda} \\
(\mathrm{W} / \mathrm{mK})\end{array}$ \\
\hline Cereal Straw $^{1}$ & Pellets & 110 & 0.050 \\
Cereal Straw $^{2}$ & Bales & 100 & 0.055 \\
Hemp $^{1}$ & Board & 43 & 0.042 \\
Hemp $^{2}$ & Board & 44 & 0.045 \\
Wood $^{1}$ & Board & 172 & 0.042 \\
Wood $^{2}$ & Board & 150 & 0.045 \\
Coconut $^{1}$ & Board & 95 & 0.045 \\
Coconut $^{2}$ & Board & 95 & 0.045 \\
Flax $^{1}$ & Board & 36 & 0.039 \\
Flax $^{2}$ & Board & 50 & 0.041 \\
Cork $^{1}$ & Board & 151 & 0.039 \\
Cellulose $^{1}$ & Loose fill & 138 & 0.047 \\
\hline Average & & $\mathbf{9 9}$ & $\mathbf{0 . 0 4 5}$ \\
Sd & & $\mathbf{4 6}$ & $\mathbf{0 . 0 0 4}$
\end{tabular}

The second scenario is based on the forecast of the volume of the Spanish insulation market for the period 2013-2018 [5]. While the first scenario takes only housing refurbishment into account, in the second three different groups of constructions are considered: housing refurbishment, housing (both refurbishment and new construction) and the whole building sector.

The demand of food crop by-products (dry basis) is estimated taking into account the following assumptions:

1) Total demand is met exclusively with insulation materials based on crop by-products, i.e. their market share corresponds to the whole Spanish insulation market. This assumption over-sizes the results, since the market share of natural insulation materials is much lower, as discussed in the introduction.

2) $10 \%$ of the insulation materials correspond to binders and additives, which means that only $90 \%$ correspond to crop by-products.

3) $20 \%$ of the raw materials are lost during transportation and production.

As a result, the demand of food crop by-products $\left(\mathrm{D}_{\text {by-products }}\right)$ is calculated using the following equation:

$$
D_{\text {by-products }}=V_{\text {ins }} \cdot \delta_{\text {ins }} \cdot 0.9 \cdot 1.2
$$

where $\mathrm{V}_{\text {ins }}$ is the volume demand of insulation in $\mathrm{m}^{3}$ and $\delta_{\text {ins }}$ is the average density of existing insulations shown in Table 3. Factor 0.9 refers to assumption 2 and 1.2 to assumption 3. 


\section{Results and discussion}

\subsection{Availability of crop by-products in Spain}

Following the methodology described above, the mean annual $\mathrm{Bt}$ and $\mathrm{Ba}$ is evaluated for the triennium 2008-2010. Results are shown in Figure 2.

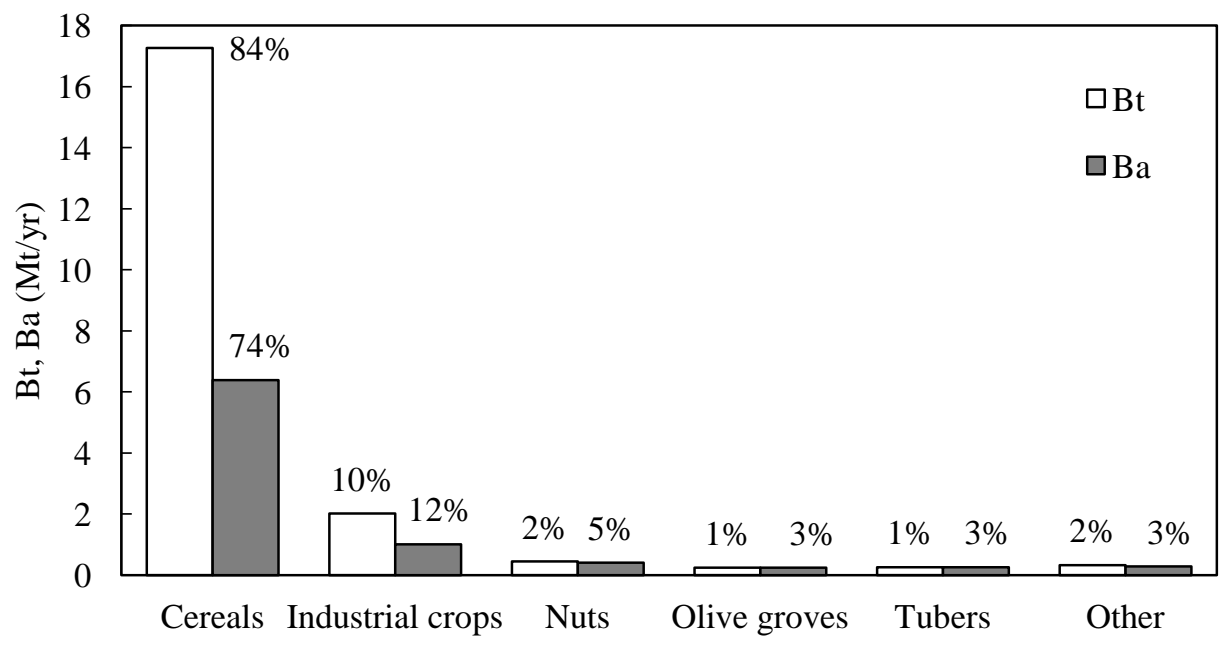

Figure 2. Bt and Ba produced annually in Spain (dry basis).

As expected, cereals provide the major part of crop by-products, basically in the form of straw. During the period studied, an average of 20.6 MT of crop by-products was produced in Spain yearly, of which 17.3 MT where from cereals (84\%). When evaluating Ba (8.6 MT.year ${ }^{-1}$ ), cereals by-products are still the most numerous, even if restrictions on exploitation are applied only for cereals and industrial crops. Ba from cereal crops is 6.4 MT -year-1, which corresponds to $74 \%$ of the total $\mathrm{Ba}$. Industrial crop by-products correspond to $12 \%$ of the $\mathrm{Ba}$ and come mainly from sunflowers.

Among cereals, barley straw and wheat straw are the most abundant, followed by corn stalks and rice straw and husks. Sunflower by-products are also copious, even exceeding some types of cereals such as rye or oats. These top five crop by-products account for $77 \%$ of $\mathrm{Ba}$, and their availability is evaluated over a longer period of time (from 2004 to 2011). Results are shown below in Figure 3.

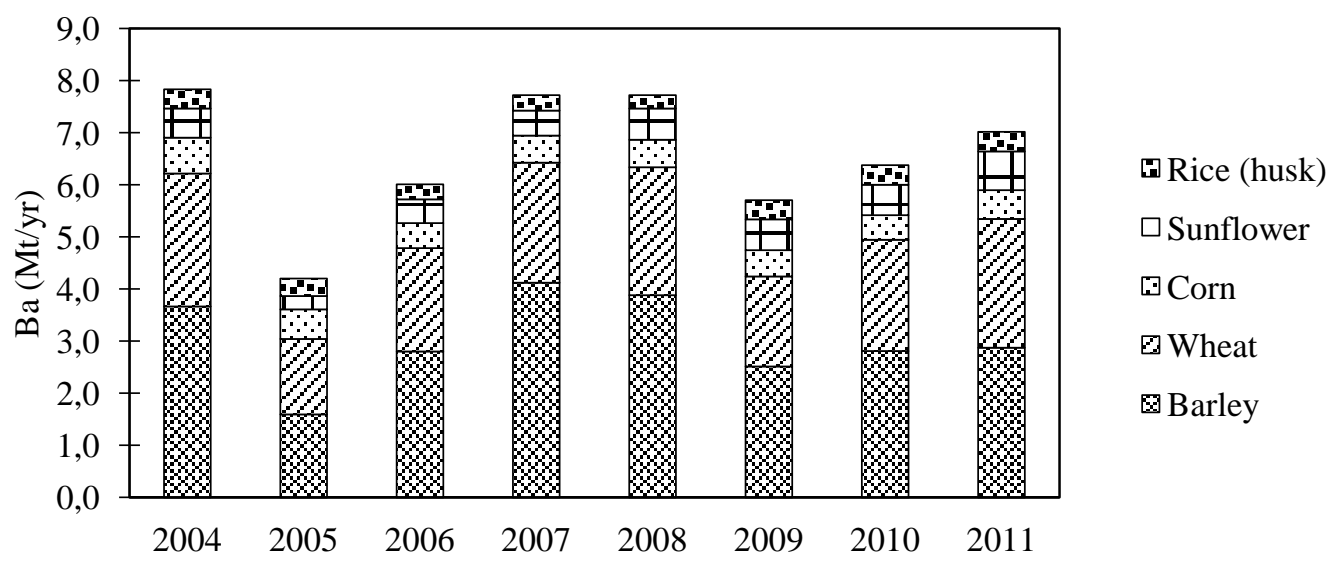

Figure 3. Fluctuation over time of the Ba for the top five crops in Spain. 
On average, $\mathrm{Ba}$ for the top five crops is $6.6 \mathrm{MT}$-year-1. Even if $\mathrm{Ba}$ tends to be constant over time, important fluctuations are revealed, possibly as a consequence of climatic conditions and other drivers such as crop policies, etc. The standard deviation is 1.2 MT.

The distribution of this production throughout the territory is shown in Figure 4. Ba from barley and wheat is distributed throughout the whole country, while Ba from corn and sunflowers are complementary. The northern and central areas and Seville concentrate a large part of the available crop by-products in Spain. Rice Ba are confined to specific areas such as Valencia and the south-west of the country.

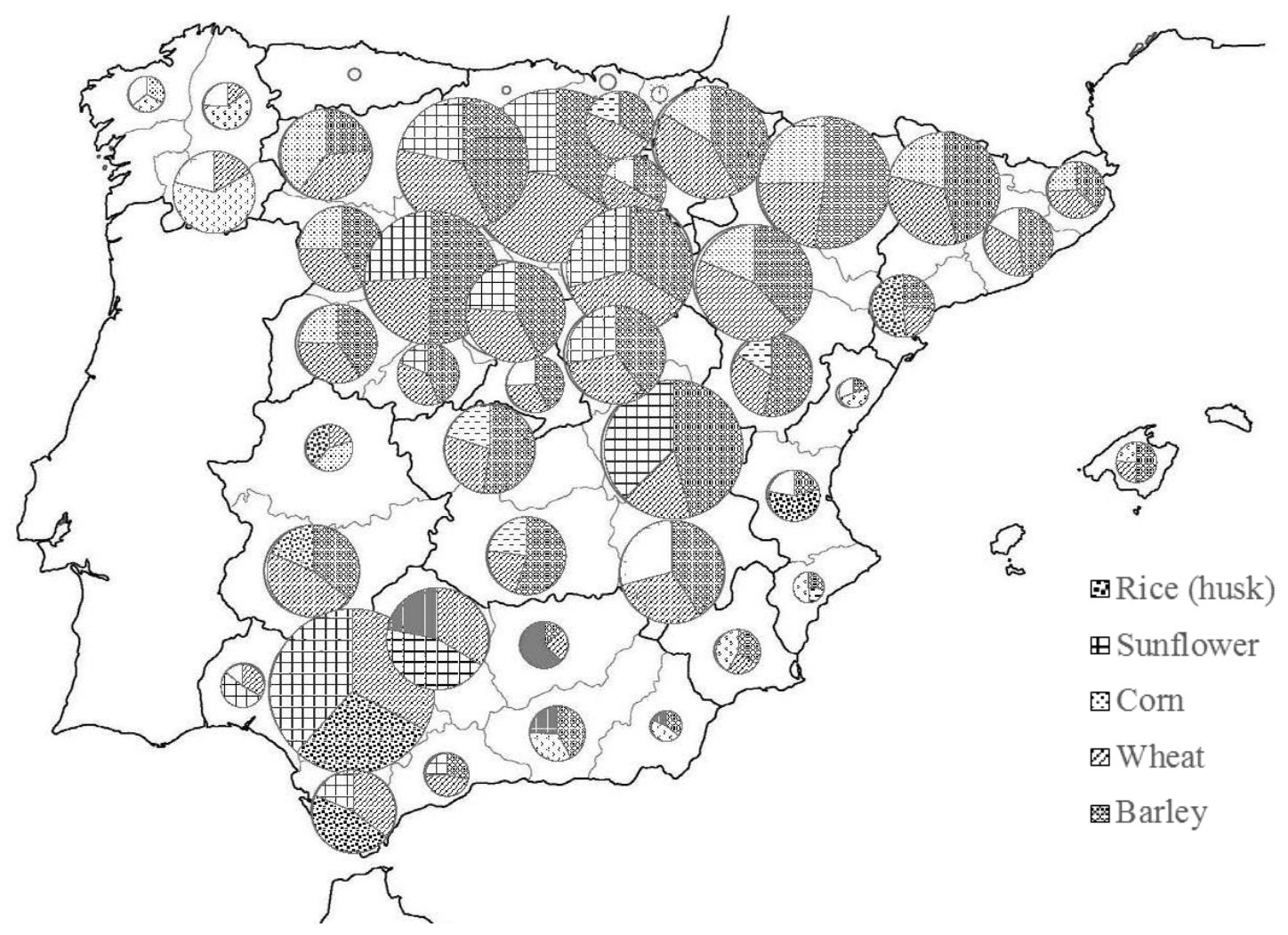

Figure 4. Distribution of main crop by-products by province (Data for 2010)

\subsection{Estimation of demand for crop by-products as raw materials for natural thermal insulations}

A range for the demand of crop by-products is estimated according to the two different scenarios described in the methodology. Results are shown in Table 4. The two chosen scenarios diverge widely in their forecasts: the first presupposes a break in the trend in order to meet political goals, while the second represents a continuation of the present situation. Thus, in the first scenario, about $0.5 \mathrm{MT}$ of cop by-products are needed each year to cover the demand for housing refurbishment, while in the second this figure falls to $0.06 \mathrm{MT}$. In this latter scenario, 1.1 MT of crop by-products are needed to meet the whole demand for building insulation materials in Spain. 
A crosscheck between demand and availability shows that $16.4 \%$ of the top five Ba would satisfy the total annual demand for building insulation materials. Less than 0.5 MT of crop byproducts would be used in housing refurbishment, which corresponds to the availability of corn by-products and represents about $7.6 \%$ of Ba top five.

These results therefore suggest that insulation based on crop by-products could be developed without competing with existing uses or compromising soil fertility, since it would require $5.3 \%$ and $12.6 \%$ of the total Bt and Ba respectively.

Table 4. Estimation of demand for crop by-products under the two scenarios evaluated. Bt5 and Ba5 correspond to the top five crops.

\begin{tabular}{ll|ccccc}
\hline \multicolumn{2}{c|}{ SCENARIO } & \multicolumn{4}{c}{ DEMAND } \\
& & Insulation (m3) & Crop by-products (T) & Bt5 (\%) & Ba5 (\%) \\
\hline \multirow{2}{*}{ GRT } & Housing & Refur & $4,656,172$ & 497,838 & 2.8 & 7.5 \\
\hline \multirow{2}{*}{ RW } & Housing & Refur & 537,822 & 57,504 & 0.3 & 0.9 \\
& & Refur + new constr & $3,229,737$ & 345,323 & 1.9 & 5.2 \\
& \multirow{2}{*}{ Building } & Refur + new constr & $10,102,969$ & $1,080,209$ & 6.1 & 16.4 \\
\hline
\end{tabular}

\section{Conclusions}

The availability of crop by-products to be used as raw materials for building thermal insulations is evaluated. Availability is compared to the demand forecast on the basis of two different scenarios. Although the results vary greatly from one scenario to another, they indicate an order of magnitude from which it is possible to draw some conclusions.

A sustainable production of insulation materials based on crop by-products seems to be feasible. The results show that by and large enough crop by-products exist to meet all the estimated demand without compromising other existing uses or soil fertility. Even when demand is greatly over-sized, it would require less than $17 \%$ of the available crop by-products produced every year in Spain. Available corn by-products would be enough to insulate between 250,000 and 450,000 dwellings annually.

Thus, insulation production would not compete with other emerging industries such as energy production in the use of these raw materials.

Future research should explore the technical feasibility and characterization of insulations based on crop by-products, especially from barley, wheat, corn, rice and sunflowers. These top five crop by-products represent $77 \%$ of the total available by-products (6.6 MT.year-1).

Potentially, insulations based on crop by-products constitute an economically viable and sustainable alternative to existing materials, depending on production processes. Similar production processes to those implemented for existing natural thermal insulations would foreseeably be required. 


\section{Acknowledgements}

The authors would like to thank to Generalitat de Catalunya for the quality accreditation given to the research group GICITED (2014 SGR 1298) and for the support under a PhD studentship FI-DGR.

\section{Bibliography}

[1] Cuchí A, Sweatman P, Informe GTR. Una visión-país para el sector de la edificación en España. Hoja de ruta para un nuevo sector de la vivienda. (2011)

[2] Latif E., Wijeyesekera DC, Newport D, Tucker S. Potential for research on hemp insulation in the UK construction sector, University of East London, School of Computing, Information Technology and Engineering, Londres. (2010): 143-150.

[3] Cuchí A, Sweatman P, Pagès A. Informe GTR 2012. Una visión-país para el sector de la edificación en España. Plan de acción para el nuevo sector de la vivienda. (2012)

[4] Rockwool (internal document, unpublished). Spain total insulation market. Market sizes and market shares 2010-2018. Focus year 2013.

[5] Yates T. Review. The use of non-food crops in the UK construction industry. Journal of the science of food and agriculture (2006); 86:1790-1796

[6] Kretschmer B, Allen B, Hart K. Mobilising cereal straw in the EU to feed advanced biofuel production. Report produced for Novozymes. Institute for European Environmental Policy (IEEP), London. (2012).

[7] Ministerio de Agricultura, Alimentación y Medio Ambiente. Anuario de estadística. Superficies y producciones anuales de cultivos. [Online] http://www.magrama.gob.es/es/ estadistica/temas/estadisticas-agrarias/agricultura/superficies-producciones-anuales-cultivos/ (verified 08/07/2014)

[8] McDonough W, Braungart M. Cradle to Cradle: Remaking the Way We Make Things. North Point Press. (2002)

[9] Pinto J, Paiva A, Varum H, Costa A, Cruz D, Pereira S, et al. Corn's cob as a potential ecological thermal insulation material. Energy and Buildings (2011); 43: 1985-1990

[10] Osanyintola OF, Simonson CJ. Moisture buffering capacity of hygroscopic building materials: Experimental facilities and energy impact. Energy and Buildings (2006); 38: 12701282

[11] Conteville L, Den Hartigh C. Les écomatériaux en France. État des lieux et enjeux dans la rénovation thermique des logements. Les Amis de la Terre (2009): 14

[12] Bloomberg New Energy Finance (2010). Next-generation ethanol and biochemicals: what's in it for Europe? [Online] https://bnef.com/PressReleases/view/126 (verified 08/07/2014) 
[13] Évaluation des ressources disponibles en France. Observatoire national des ressources en biomasse. FranceAgriMer. (2012). [Online] http://www.franceagrimer.fr/content/download/ 15926/119849/file/DOC_FINAL_Obs_Biomasse_12-12.pdf (verified 08/07/2014)

[14] Copeland J, Turley D. National and regional supply/demand balance for agricultural straw in Great Britain. The National Non-Food crop Centre. (2008) [Online] http://www.nnfcc.co.uk/ tools/national-and-regional-supply-demand-balance-for-agricultural-straw-in-great-britain

(verified 08/07/2014)

[15] Scarlat N, Martinov M, Dallemand JF. Assessment of the availability of agricultural crop residues in the European Union: Potential and limitations for bioenergy use. Waste management (2010); 30(10): 1889-1897.

[16] Fischer G, Hizsnyik E, Prieler S, van Velthuizen H. Assessment of biomass potentials for biofuel feedstock production in Europe: Methodology and results. REFUEL project report, July. (2007). [Online] http://biofuelstp.eu/viewreport.php?viewid=44 (verified 08/07/2014)

[17] Ericsson K, Nilsson LJ. Assessment of the potential biomass supply in Europe using a resource-focused approach. Biomass and Bioenergy (2005); 30: 1-15

[18] Jölli D, Giljum S. Unused biomass extraction in agriculture, forestry and fishery. Sustainable Europe Research Institute. (2005). [Online] http://seri.at/en/publications/2009/09/13/unused-biomass-extraction-in-agriculture-forestry-andfishery/ (verified 08/07/2014)

[19] Hernández CG, Fuertes A. Biomasa vegetal no alimentaria producida en España con posibilidad de uso energético. ITEA (2011); 107 (3): 209-225

[20] Singer S. The energy report. 100\% renewable energy by 2050, in WWF The energy report 2011, WWF International: Switzerland: 1-256

[21] Di Blasi C, Tanzi V, Lanzetta M. A study on the production of agricultural residues in Italy. Biomass and Bioenergy (1997); 12 (5): 321-331

[22] Cabrera M. Vera A, Cornejo JM, Ordas I, Tolosana E, Ambrosio Y, et al. Evaluación del potencial de energía de la biomasa. Estudio técnico PER 2011-2020. IDAE (2011) [Online] http://idae.electura.es/libros/516/ (verified 10/08/2014)

[23] Lacasta C, Meco R. Manejo de agrosistemas de cereales. Manual de Agricultura y Ganadería Ecológica. (2005).

[24] Lübbeke I, Anderson J. Smart use of residues. Exploring the factors affecting the sustainable extraction rate of agricultural residues for advanced biofuels. Briefing paper. WWFWorld Wide Fund For Nature (2012). [Online] http://awsassets.panda.org/downloads/wwf_smart_use_finale_version.pdf (verified 08/07/2014)

[25] Martínez F X. Gestión y tratamiento de residuos agrícolas. [Online] http://www.infoagro. com/hortalizas/residuos_agricolas2.htm (verified 22/02/2013)

[26] Canet R. Uso de materia orgánica en Agricultura. Instituto valenciano de investigaciones agrarias (IVIA) [Online] http://www.ivia.es/rcanet/descargas/MO_en_Agricultura.pdf (verified 08/07/2014) 
[27] Pfundstein M, Gellert R, Spitzner MH, Rudolphi A. et al. Insulating materials. Principles, materials, applications. C. Schulz (Ed.) DETAIL Practice. Architektur-Dokumentation GmbH \& Co., Munich (2008) 